\title{
Biology of the TAM Receptors
}

\author{
Greg Lemke \\ Molecular Neurobiology Laboratory, Immunobiology and Microbial Pathogenesis Laboratory, \\ The Salk Institute, La Jolla, California 92037 \\ Correspondence: lemke@salk.edu
}

The TAM receptors-Tyro3, Axl, and Mer-comprise a unique family of receptor tyrosine kinases, in that as a group they play no essential role in embryonic development. Instead, they function as homeostatic regulators in adult tissues and organ systems that are subject to continuous challenge and renewal throughout life. Their regulatory roles are prominent in the mature immune, reproductive, hematopoietic, vascular, and nervous systems. The TAMs and their ligands_-Gas6 and Protein S-are essential for the efficient phagocytosis of apoptotic cells and membranes in these tissues; and in the immune system, they act as pleiotropic inhibitors of the innate inflammatory response to pathogens. Deficiencies in TAM signaling are thought to contribute to chronic inflammatory and autoimmune disease in humans, and aberrantly elevated TAM signaling is strongly associated with cancer progression, metastasis, and resistance to targeted therapies.

$T^{\mathrm{h}}$ he name of the TAM family is derived from the first letter of its three constituentsTyro3, Axl, and Mer (Prasad et al. 2006). As detailed in Figure 1, members of this receptor tyrosine kinase (RTK) family were independently identified by several different groups and appear in the early literature under multiple alternative names. However, Tyro3, Axl, and Mer (officially c-Mer or MerTK for the protein, Mertk for the gene) have now been adopted as the NCBI designations. The TAMs were first grouped into a distinct RTK family (the Tyro3/7/12 cluster) in 1991, through PCR cloning of their kinase domains (Lai and Lemke 1991). The isolation of full-length cDNAs for Axl (O'Bryan et al. 1991), Mer (Graham et al. 1994), and Tyro3 (Lai et al. 1994) confirmed their segregation into a structurally distinctive family of orphan RTKs (Manning et al. 2002b). The two ligands that bind and activate the TAMs-Gas6 and Protein S (Pros1) - were identified shortly thereafter (Ohashi et al. 1995; Stitt et al. 1995; Mark et al. 1996; Nagata et al. 1996).

Subsequent progress on elucidating the biological roles of the TAM receptors was considerably slower and ultimately required the derivation of mouse loss-of-function mutants (Camenisch et al. 1999; Lu et al. 1999). The fact that $\mathrm{TyrO}^{-/-}, \mathrm{Axl}^{-/-}$, and $\mathrm{Mer}^{-/-}$mice are all viable and fertile permitted the generation of a complete TAM mutant series that included all possible double mutants and even triple mutants that lack all three receptors ( $\mathrm{Lu}$ et al. 1999). Remarkably, these Tyro ${ }^{-/-} A x l^{-/-}$ $\mathrm{Mer}^{-1-}$ triple knockouts (TAM TKOs) are viable, and for the first 2-3 wk after birth, superficially indistinguishable from their wild-type counterparts (Lu et al. 1999). Because many

Editors: Joseph Schlessinger and Mark A. Lemmon

Additional Perspectives on Signaling by Receptor Tyrosine Kinases available at www.cshperspectives.org

Copyright (C) 2013 Cold Spring Harbor Laboratory Press; all rights reserved; doi: 10.1101/cshperspect.a009076

Cite this article as Cold Spring Harb Perspect Biol 2013;5:a009076 
G. Lemke

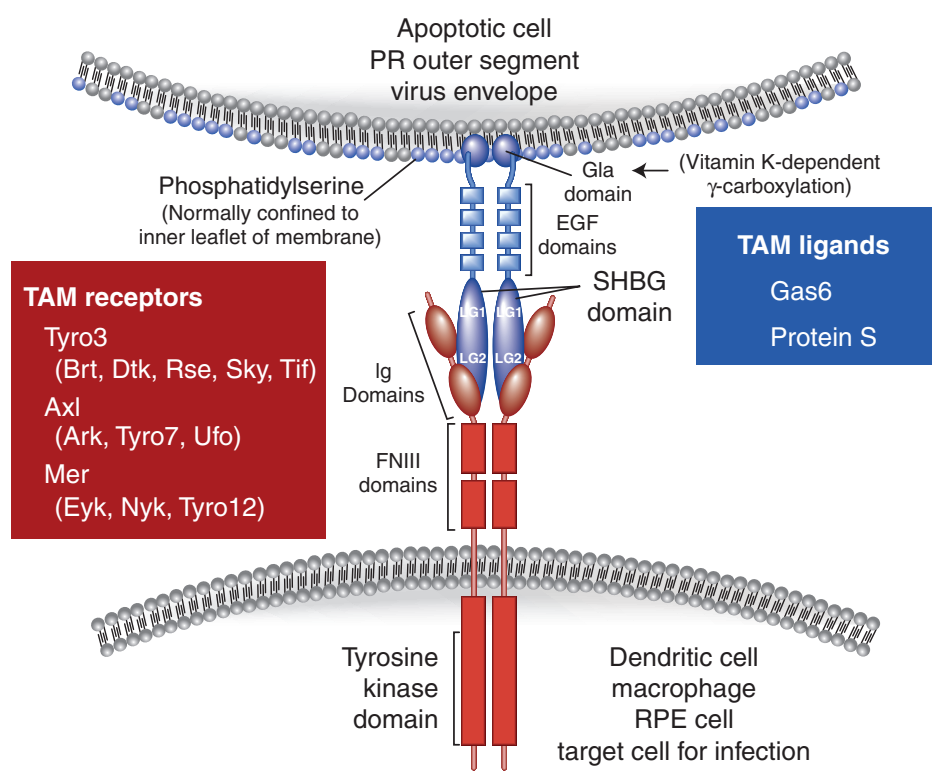

Figure 1. TAM receptors and ligands. The TAM receptors (red) are Tyro3 (Lai and Lemke 1991; Lai et al. 1994)— also designated Brt (Fujimoto and Yamamoto 1994), Dtk (Crosier et al. 1994), Rse (Mark et al. 1994), Sky (Ohashi et al. 1994), and Tif (Dai et al. 1994); Axl (O’Bryan et al. 1991)—also designated Ark (Rescigno et al. 1991), Tyro7 (Lai and Lemke 1991), and Ufo (Janssen et al. 1991); and Mer (Graham et al. 1994)—also designated Eyk (Jia and Hanafusa 1994), Nyk (Ling and Kung 1995), and Tyro12 (Lai and Lemke 1991). The TAMs are widely expressed by cells of the mature immune, nervous, vascular, and reproductive systems. The TAM ligands (blue) are Gas6 and Protein S (Pros1). The carboxy-terminal SHBG domains of the ligands bind to the immunoglobulin (Ig) domains of the receptors, induce dimerization, and activate the TAM tyrosine kinases. When $\gamma$-carboxylated in a vitamin-K-dependent reaction, the amino-terminal Gla domains of the dimeric ligands bind to the phospholipid phosphatidylserine expressed on the surface on an apposed apoptotic cell or enveloped virus. See text for details. (From Lemke and Burstyn-Cohen 2010; adapted, with permission, from the authors.)

RTKs play essential roles in embryonic development, even single loss-of-function mutations in RTK genes often result in an embryonic-lethal phenotype (Gassmann et al. 1995; Lee et al. 1995; Soriano 1997; Arman et al. 1998). The postnatal viability of mice in which an entire RTK family is ablated completely - the TAM TKOs can survive for more than a year ( $\mathrm{Lu}$ et al. 1999)—is therefore highly unusual. Their viability notwithstanding, the TAM mutants go on to develop a plethora of phenotypes, some of them debilitating (Camenisch et al. 1999; Lu et al. 1999; Lu and Lemke 2001; Scott et al. 2001; Duncan et al. 2003; Prasad et al. 2006). Almost without exception, these phenotypes are degenerative in nature and reflect the loss of TAM signaling activities in adult tissues that are subject to regular challenge, renewal, and remodeling. These activities are the subject of this review.

\section{TAM RECEPTOR/LIGAND STRUCTURE AND SIGNALING FEATURES}

The extracellular domains of TAM receptors are composed of two structural modules that are used repeatedly in other RTK ectodomains, but that are configured in a defining two-plustwo combination in the TAMs (Fig. 1). The amino-terminal regions of these ectodomains carry tandem immunoglobulin-related domains that mediate ligand binding (Heiring et al. 2004; Sasaki et al. 2006), which are followed by tandem fibronectin type III repeats (O'Bryan et al. 1991; 
Graham et al. 1994; Lai et al. 1994; Lemke and Rothlin 2008). All three TAM receptors have a single-pass trans-membrane domain, and all carry a catalytically competent protein-tyrosine kinase (Fig. 1). High-resolution crystal structures have been determined for the Tyro3 (Powell et al. 2012) and Mer kinase domains (Huang et al. 2009; Liu et al. 2012).

In many cells, the activation of this tyrosine kinase is coupled to the downstream activation of the phosphoinositide 3 kinase (PI3K)/AKT pathway. Most of this downstream PI3K signaling is nucleated through a TAM-autophosphorylated Grb2-binding site, which is located 18 residues carboxy terminal to the kinase domain and is conserved in all three TAMs (Fig. 2) (Fridell et al. 1996; Ling et al. 1996; Braunger et al. 1997; Goruppi et al. 1997; Georgescu et al. 1999; Lan et al. 2000; Ming Cao et al. 2001; Son et al. 2007; Tibrewal et al. 2008; Weinger et al. 2008). Coupling to phospholipase C, ERK1/2, Ras, and MAP kinase activation have also been described in many different cells (Keating et al. 2010; Lijnen et al. 2011; Ou et al. 2011). These TAM-activated signaling pathways (Fig. 2), which involve what might be called "the usual suspects" downstream from RTK activation, operate in all TAM-expressing cells. Macrophages, dendritic cells, and other sentinel cells of the immune system, however, also express cytokine receptor signaling systems-in particular, the type I interferon (IFN) receptor-that are directly coupled to, interact with, and are codependent on the TAM receptors. In these cells, the TAM-activated PI3K/AKT pathway is often dominated and obscured by a stronger TAM-activated JAK/STAT signaling pathway (Zong et al. 1996; Rothlin et al. 2007; Lemke and Rothlin 2008). Differential TAM activation of PI3K/AKT versus JAK/STAT signaling may be important for the differential activation of distinct TAM-regulated bioactivities (Fig. 2).

TAM receptors are among the last RTKs to have appeared during evolution (Manning et al. 2002a,b). Unlike the FGFR, EGFR, or ROR families, for example, there are no TAM representatives in either Drosophila or Caenorhabditis elegans. A single TAM-like receptor gene and a single Gas6/Pros1-like ligand gene are first seen in the genomes of prevertebrate urochordates such as Ciona (Kulman et al. 2006; Lemke and Rothlin 2008), coincident with the first appearance of type I and type II cytokines (e.g., interferons) and cytokine receptors.

The two TAM ligands_-Gas6 and Pros1 (Manfioletti et al. 1993; Stitt et al. 1995; Mark et al. 1996) — are large ( $\sim 80-\mathrm{kDa})$ proteins that are $\sim 42 \%$ identical and share the same multidomain arrangement (Fig. 1). They have two unusual structural features that are key to their bioactivities. The first is a carboxy-terminally positioned "sex hormone-binding globulin" (SHBG) domain composed of two laminin G domains (Fig. 1). This SHBG domain binds to the Ig domains of the receptors and induces their dimerization and subsequent kinase activation (Nyberg et al. 1997; Tanabe et al. 1997; Evenas et al. 2000; Sasaki et al. 2002, 2006). The second is a so-called Gla domain positioned at the very amino terminus of both Gas6 and Pros1 (Stitt et al. 1995; Ishimoto et al. 2000; Rajotte et al. 2008). (The SHBG and Gla domains are separated by four EGF-related domains.) This $\sim 60$-amino-acid Gla domain is rich in glutamic acid residues whose $\gamma$-hydroxyl groups are posttranslationally carboxylated in a vitamin K-dependent modification (Huang et al. 2003; Li et al. 2004; Bandyopadhyay 2008). Gas6 and Pros1 share Gla domains with several proteins of the blood coagulation cascade, such as factors VII, IX, and X (Dahlback 2000; Stafford 2005). Indeed, in addition to acting as a TAM ligand, Pros1 also functions as an anticoagulant in this cascade (Dahlback 2000; Burstyn-Cohen et al. 2009).

$\gamma$-Carboxylation of Gla domains allows them to bind to phosphatidylserine (PtdSer). In most cells, the activity of a set of $\mathrm{P}_{4}$ ATPases-so-called flippases-ensures that this phospholipid is confined to the inner, cytoplasm-facing leaflet of the plasma membrane (van Meer et al. 2008). In activated platelets and apoptotic cells (among other sites), these flippases are disabled such that PtdSer is displayed on the extracellular membrane surface as well. For apoptotic cells (ACs), extracellularly displayed PtdSer is among the most potent "eat-me" signals by which these dead cells are 


\section{G. Lemke}
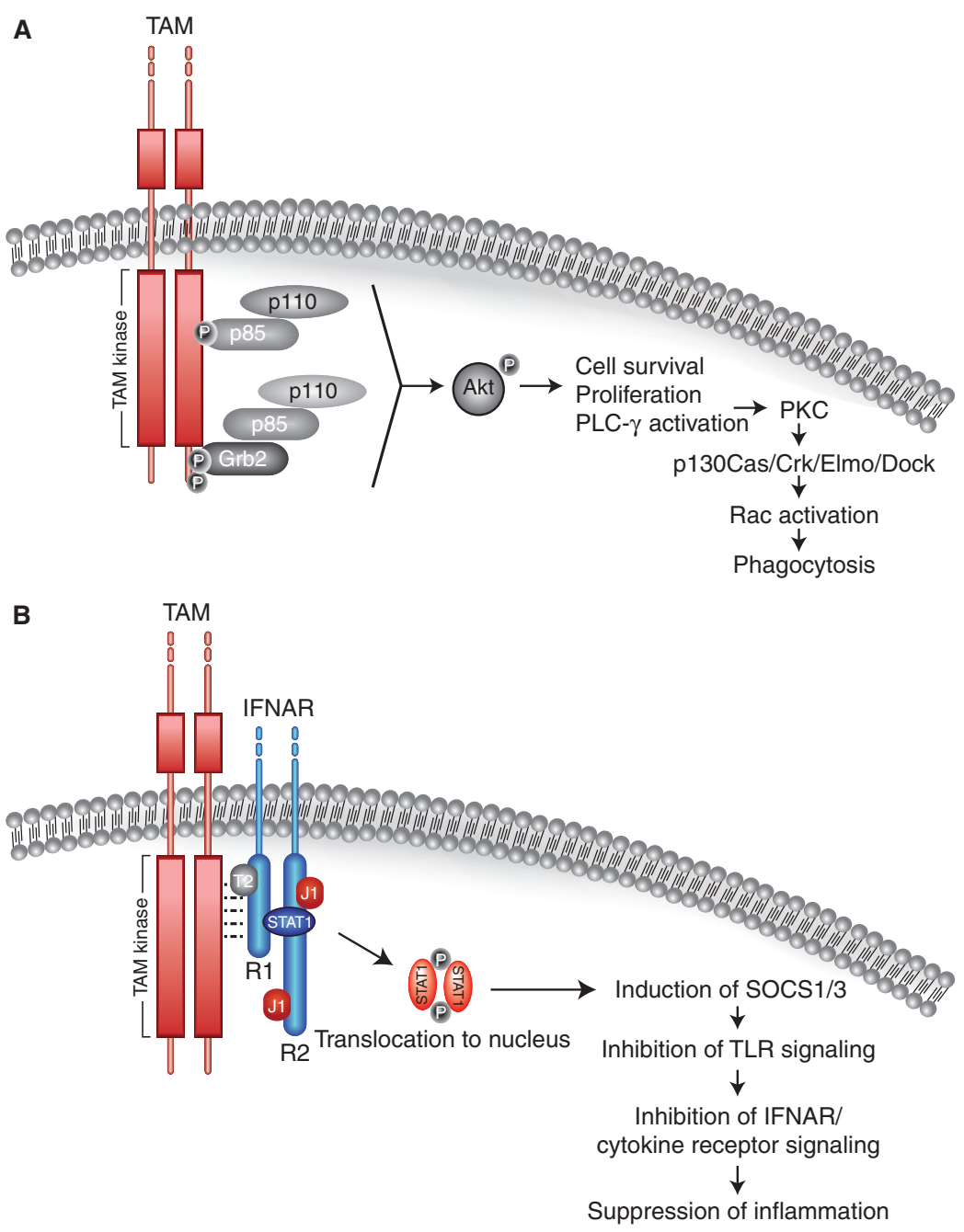

Figure 2. TAM receptor signaling pathways. (A) Free TAMs. As receptor dimers, activated TAM proteins drive a conventional RTK signaling pathway that is dominated by the phosphorylation and activation of Akt. The positions of major tyrosine autophosphorylation sites shared between Tyro3, Axl, and Mer are indicated (P). The tyrosine immediately downstream from the kinase domain (Y821 in human Axl) is bound by the SH2 domain of Grb2, which recruits the p85 subunit of PI3 kinase through an SH3 (Grb2)-proline-rich domain ( p85) interaction. Alternatively, p85 can bind this phosphotyrosine directly using its own SH2 domain. P85 also binds to the indicated phosphotyrosine within the kinase domain (see, e.g., Weinger et al. 2008). Mobilization of the joint p85/p110 PI3K complex results in the downstream phosphorylation and activation of Akt. Mer activation has also been found to drive the downstream activation of PLC- $\gamma$, by a mechanism that is not delineated biochemically (Tibrewal et al. 2008). These pathways are required for TAM regulation of cell survival and the mobilization of the actin cytoskeleton required for the engulfment of apoptotic cells by phagocytes. (B) TAM receptors complexed with the type I interferon receptor (IFNAR). In dendritic cells, TAM receptorswhen activated by the binding of a TAM ligand—form a coimmunoprecipitable complex specifically with the R1 (or $\alpha$ ) chain of the IFNAR (Rothlin et al. 2007). This may be associated with the activation of Jak1 (J1) (Zong et al. 1996). Direct activation of the hybrid TAM-IFNAR receptor by the addition of Gas6 leads to the rapid tyrosine phosphorylation and activation of Stat1. This dimeric transcription factor then translocates to the nucleus, where it drives the expression of the cytoplasmic cytokine inhibitors SOCS1 and 3. This pathway is required for the inhibition of inflammatory responses in dendritic cells (Rothlin et al. 2007; Lemke and Rothlin 2008). See text for details. 
recognized by phagocytes (Ravichandran 2010). Gla-domain-containing proteins can therefore bind the surface membranes of ACs. As discussed below, the interaction of the $\gamma$-carboxylated amino-terminal Gla domains of Gas6 and Pros1 with a PtdSer-containing membrane is a crucial feature of their activation of TAM receptors, and it is possible that in vivo these ligands always signal in the context of membrane association.

As depicted in Figure 1, Gas6 and Pros1 appear to bind to TAM receptors as dimers, and for Pros1, multimerization is required for TAM activation (Uehara and Shacter 2008). Apart from this, receptor-ligand pairing relationships and signaling interactions for the TAM system remain incompletely understood. For example, we do not know the extent to which Prosl and Gas6 may heterodimerize, and if this occurs, how receptor binding and activation profiles of the heterodimer may differ from those of Gas6 or Pros1 homodimers. Similarly, the extent to which individual TAM receptors may heterodimerize in different cellular settings is also poorly understood. The preponderance of evidence indicates that Gas6 functions as a ligand for all three TAM receptors, with reduced binding affinity for Mer relative to Axl and Tyro3 (Ohashi et al. 1995; Stitt et al. 1995; Mark et al. 1996; Nagata et al. 1996; Chen et al. 1997; Lemke and Rothlin 2008). Pros1, in contrast, appears to bind and activate Tyro3 and Mer, with little or no affinity for Axl (Stitt et al. 1995; Prasad et al. 2006; Lemke and Rothlin 2008; Uehara and Shacter 2008; Zhong et al. 2010). In an active area of research, the extent to which Gas6 and/ or Pros1 contribute to the observed activity of specific TAM receptors has just begun to be dissected genetically. As discussed below, the first example of such a differential genetic analysis has recently been reported for Gas6 and Pros1 action in Mer-expressing retinal pigment epithelial cells of the eye (Burstyn-Cohen et al. 2012).

In some settings, the biologically relevant cellular sources of Gas6 and/or Pros1 required for TAM activation also remain to be determined. In several cell types, TAM signaling appears to be autocrine/paracrine, in that a TAM-positive cell has frequently been found to express Pros1 and/or Gas6 (Lu et al. 1999; Prasad et al. 2006; Rothlin et al. 2007). Pros1 is expressed at $\sim 300 \mathrm{~nm}$ in the blood, into which it is secreted by hepatocytes and vascular endothelial cells (Burstyn-Cohen et al. 2009). (In contrast, Gas6 is present at $\leq 0.2 \mathrm{~nm}$ in serum, and nearly all of this is complexed with soluble Axl ectodomain [Ekman et al. 2010].) Tyro3and Mer-expressing cells that transit through the circulation are therefore exposed to saturating levels of Pros1. In the immune system, an important source of Pros1 for TAM-expressing macrophages and dendritic cells (see below) may be activated T cells (Smiley et al. 1997).

\section{TAM MEDIATION OF THE PHAGOCYTOSIS OF APOPTOTIC CELLS}

TAM receptor signaling plays an especially important role in the engulfment and phagocytic clearance of apoptotic cells (ACs) and membranes in adult tissues (Lemke and Rothlin 2008; Lemke and Burstyn-Cohen 2010). In this process, a TAM ligand, Gas6 or Pros1, serves as a "bridging molecule" that physically links a TAM receptor, generally Mer or Axl, expressed on the surface of the phagocyte, to PtdSer, which is displayed on the surface of the AC that will be engulfed (Fig. 1) (Wu et al. 2006; Nagata et al. 2010). At the same time, this ligand must also activate the tyrosine kinase activity of the TAM receptor for the process of phagocytosis to go forward (Scott et al. 2001; Mahajan and Earp 2003; Tibrewal et al. 2008; Todt et al. 2008; Lemke and Burstyn-Cohen 2010).

The first phenotype described in the TAM TKOs was male infertility, which is tied to the degenerative death of nearly all germ cells in the testes ( $\mathrm{Lu}$ et al. 1999). This cell death results from a dramatic pileup of AC corpses in the seminiferous tubules and is degenerative rather than developmental in nature (Lu et al. 1999); this is due to the loss of TAM receptor function in Sertoli cells (Lu et al. 1999; Chen et al. 2009; Sun et al. 2010). These somatic support cells are phagocytes; among their most important roles is the PtdSer-dependent clearance of the enormous number of apoptotic germ cells that are generated during meiosis (Kawasaki et al. 2002). 
G. Lemke

It has been estimated that more than half of the meiotic population dies during each cycle of mammalian spermatogenesis, and thus the clearance of these AC corpses (on the order of $10^{8} / \mathrm{d}$ in a human male) by Sertoli cells is critical. This process is TAM dependent; Sertoli cells express all three TAMs and both TAM ligands, and in the absence of TAM signaling, the phagocytosis of apoptotic germ cells in the testes is significantly attenuated (Lu et al. 1999).

A similarly dramatic phenotype is seen in the retina of both TAM TKOs and $\mathrm{Mer}^{-/-}$single mutants. These mutants are born with normal retinas, but by 2 mo after birth, most of their photoreceptors (PRs) have died (Lu et al. 1999; Duncan et al. 2003). This is a nonautonomous phenotype with respect to PRs, in that these cells do not express the TAMs. Rather, both Mer and Tyro3 are expressed by cells of the retinal pigment epithelium (RPE) (Prasad et al. 2006). Like Sertoli cells in the testes, RPE cells are phagocytes (Sparrow et al. 2010). Unlike Sertoli cells, however, they do not engulf ACs. Rather, the apical microvilli of these cells engulf and metabolize only part of a living cell-the distal ends of PR outer segments. These outer segments (OS) are the rhodopsin-containing organelles in which light is detected. PRs synthesize and insert new membrane at the proximal base of their OS every day, and the distal tips of these organelles are phagocytozed by RPE cells_-also on a daily basis - to remove toxic oxidative products generated by phototransduction and to maintain a constant OS length (Prasad et al. 2006; Coleman et al. 2009; Strick et al. 2009; Nandrot and Dufour 2010). In $\mathrm{Mer}^{-/}$mice, RPE cells differentiate normally but fail to perform this phagocytosis, which leads to the apoptotic death of nearly all PRs (Feng et al. 2002; Duncan et al. 2003). Unlike the situation with germ cells in the testes, PR apoptosis does not occur normally but is instead triggered by the failure of mutant RPE cells to phagocytose PR OS. Consistent with the phenotype of the $\mathrm{Mer}^{-/-}$mice, the PR degeneration seen in the Royal College of Surgeons rat, a decades-old model of retinitis pigmentosa (Bourne et al. 1938; Edwards and Szamier 1977), has been found to be due to mutation of the rat Mertk gene
(D'Cruz et al. 2000; Nandrot and Dufour 2010); and in humans, 12 distinct pathogenic sequence variants in the Mertk gene lead to inherited forms of retinitis pigmentosa and retinal dystrophy (Gal et al. 2000; Ostergaard et al. 2011). Gas6 and Pros 1 have been found to function as independent and interchangeable Mer ligands in this system. Mouse mutants in which all Gas6 or all Pros1 are singly eliminated from the retina have a wild-type number of PRs, but mice in which both Gas6 and Pros1 are removed display PR degeneration that perfectly phenocopies the degeneration seen in $\mathrm{Mer}^{-/}$mice (Burstyn-Cohen et al. 2012).

The TAMs play similarly critical roles in AC clearance by phagocytes of the immune system-most prominently macrophages (Scott et al. 2001). In humans, $>10^{9}$ ACs are generated every day, but at steady state, these dead cells are nearly impossible to detect. This is because they are almost immediately cleared by macrophages and other phagocytes. In many settings, these cells rely on the eat-me signal PtdSer to recognize dead cells as targets for engulfment (Ravichandran 2010). Phagocytic removal of ACs is also prominent during the resolution phase of inflammation, when large numbers of infiltrating granulocytes and lymphocytes undergo apoptosis and must be cleared to terminate an inflammatory response (Elliott and Ravichandran 2010; Nagata et al. 2010). Incomplete phagocytosis of ACs leads to the accumulation of secondary necrotic cells, which constitute a source of self-antigens. Not surprisingly then, defects in these TAM-dependent processes are associated with the development of human autoimmune diseases (Gaipl et al. 2007; Shao and Cohen 2011), and autoimmune phenotypes are prominent features of the TAM mouse mutants (Scott et al. 2001; Seitz et al. 2007; Ait-Oufella et al. 2008; Thorp et al. 2008; Shao et al. 2009; Lemke and Burstyn-Cohen 2010).

\section{TAM REGULATION OF THE INNATE IMMUNE RESPONSE}

Mechanistically linked to their role in the phagocytosis of ACs is the role that the TAMs play in the feedback inhibition of the innate immune 
response to pathogens. This important regulatory activity has been studied in both macrophages and dendritic cells (DCs), although the mechanism of inhibition is known in detail only in the latter (Rothlin et al. 2007). DCs and other sentinel cells use Toll-like receptors (TLRs) and other pattern recognition receptors to detect the presence of invariant molecular patterns, such as lipopolysaccharide and double-stranded RNA, which are associated with bacteria, viruses, and other pathogens (Akira 2006; Beutler et al. 2006). Activation of these receptors leads to the production of proinflammatory cytokines such as tumor necrosis factor (TNF) $\alpha$, interleukin (IL)-6, and type I interferons (Fig. 3) (Iwasaki and Medzhitov 2004). Although these cytokines are required to combat infection, they are powerful agents that must be controlled after the innate immune response is mobilized, because unrestrained cytokine signaling results in chronic inflammation and can lead to a response against self (Marshak-Rothstein 2006).

In DCs, the $A x l$ gene is expressed at a modest steady-state level before pathogen encounter but is strongly induced by TLR activation and subsequently by type I IFNs through a JAKStat1-dependent mechanism (Rothlin et al. 2007). The up-regulated Axl protein then binds to and co-opts the type I IFN receptor (IFNAR) by forming a complex with the R1 chain of this receptor (Figs. 2 and 3 ). In so doing, Axl switches the IFNAR signaling modality from proinflammatory to immunosuppressive, by driving the activation of the genes encoding the suppressor of cytokine signaling (SOCS) 1 and 3 (Rothlin et al. 2007; Yoshimura et al. 2007). An SH2 domain of these cytoplasmic inhibitors binds to phosphotyrosine residues in JAK kinases that are associated with the IFNAR and other cytokine receptors (and to phosphorylated tyrosine within the receptors themselves), and a carboxy-terminal SOCS box then mediates proteosomal degradation of associated proteins. The amino-terminal regions of SOCS1 and SOCS3 also contain a kinase-inhibitory region that acts as a JAK pseudosubstrate (Yoshimura et al. 2007; Croker et al. 2008). In this way, the induced SOCS proteins, whose expression in DCs is very largely dependent on activation of the TAM-IFNAR multimeric complex, terminate the inflammatory response to pathogens (Fig. 3) (Rothlin et al. 2007).

This pathway is an important inhibitor of inflammation in DCs and macrophages. The induction of SOCS 1 and 3 by type I IFNs is markedly blunted in Axl-deficient DCs. At the same time, the induction of these proteins by direct activation of the TAM receptorsthrough addition of Gas6-is equally dependent on the presence of both the IFNAR and associated Stat1 (Rothlin et al. 2007). The codependence of the TAM and IFNAR receptor systems for immunosuppression provides an explanation for the long-standing conundrum that type I IFNs can be both proinflammatory and immunosuppressive in sentinel cells of the immune system. If a type I IFN binds to the free IFNAR, it delivers a proinflammatory stimulus, but if it binds to the TAM-IFNAR receptor complex, it drives an immunosuppressive response (Fig. 3) (Sharif et al. 2006; Rothlin et al. 2007; Lemke and Rothlin 2008). The provision of an immune stimulus-for example, through activation of TLR4 with LPS - to a TAM-deficient cell or mouse inevitably leads to a hyperelevated inflammatory response $(\mathrm{Ca}$ menisch et al. 1999; Lu and Lemke 2001; Rothlin et al. 2007). This means that deficiencies in TAM signaling are always associated with sustained immune activation and chronic inflammation.

\section{TAM SIGNALING AND AUTOIMMUNE DISEASE}

It is therefore not surprising that mouse mutants in TAM receptor genes eventually develop broad-spectrum autoimmune disease ( $\mathrm{Lu}$ and Lemke 2001; Scott et al. 2001; Radic et al. 2006; Wallet et al. 2008; Rothlin and Lemke 2010; Shao et al. 2010). This disease, which is particularly severe in $\mathrm{Axl}^{-/-} \mathrm{Mer}^{-/-}$double mutants and in TAM TKOs (Lu and Lemke 2001), has clinical features of both systemic lupus erythematosus (SLE) and rheumatoid arthritis (RA), and is characterized by swollen joints, IgG deposits in the kidneys and other tissues, and pro- 
G. Lemke

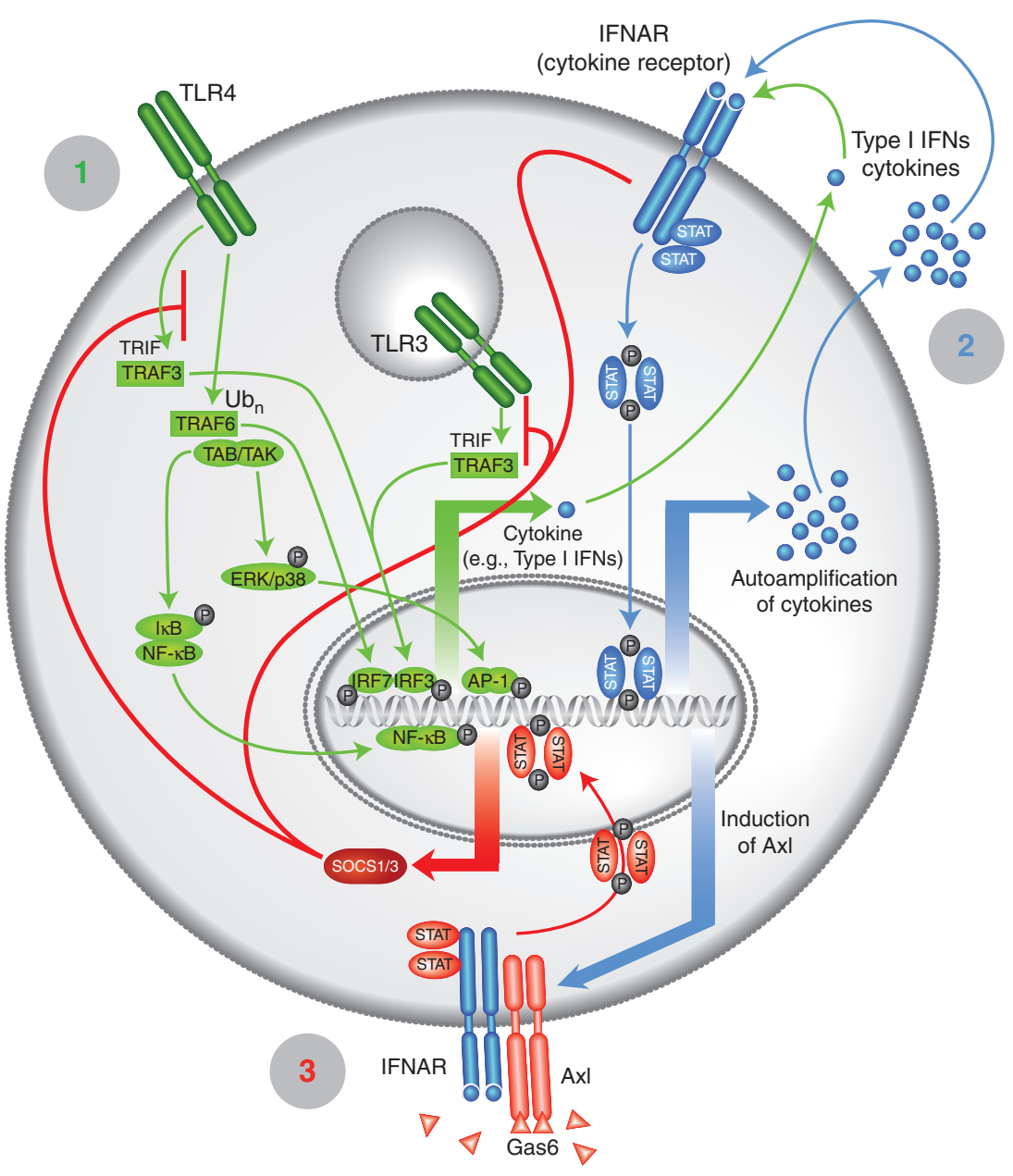

Figure 3. A TAM-regulated cycle of inflammation in dendritic cells. An initial recognition phase (1, green), mediated by Toll-like receptors (e.g., TLR4 on the cell surface and TLR3 in endosomes) and other pattern recognition receptors triggers a kinase cascade that leads to the activation of transcription factors (IRF3/7, AP-1, $\mathrm{NF}-\mathrm{\kappa B}$ ) that drive the production of an initial bolus of type I interferons (IFNs) and other proinflammatory cytokines. In a second response phase (2, blue), the levels of these cytokines are elevated via a feed-forward, JAKSTAT-dependent amplification loop. This same JAK-SAT pathway drives the transcription of the Axl gene. In a final resolution phase (3, red), the induced Axl protein binds to the R1 chain of the type I IFN receptor (IFNAR). The hybrid TAM-IFNAR receptor activates a Stat1 dimer that drives the transcription of the genes encoding SOCS1 and SOCS3. These proteins inhibit both TLR and cytokine receptor signaling, and thereby return the dendritic cell to baseline (Rothlin et al. 2007; Lemke and Rothlin 2008). The features of this self-limiting cycle predict that the provision of an immune stimulus to a dendritic cell with diminished TAM signaling will always result in a hyperelevated inflammatory response. See text for details. (From Rothlin et al. 2007; adapted and reprinted, with permission, from the author.)

nounced splenomegaly and lymphadenopathy. TAM mutant mice also display relatively high titers of antibodies to autoantigens, including double-stranded DNA, phospholipids, and ribonucleoproteins (Lu and Lemke 2001; Scott et al. 2001; Radic et al. 2006). Crossing Mer or Axl mutants into existing mouse models of autoimmune disease has generally been found to exacerbate disease (Weinger et al. 2011; Ye et al. 2011). 
Defects in the clearance of apoptotic cells and unabated type I IFN signaling-both of which are direct consequences of TAM deficiency-are also both thought to drive the development of human autoimmune diseases, including SLE, RA, and inflammatory bowel diseases (IBDs) (Gaipl et al. 2007; Ronnblom and Pascual 2008; Nagata et al. 2010). Correspondingly, several lines of evidence suggest that diminished TAM signaling may contribute to human autoimmunity (Rothlin and Lemke 2010). There is an anecdotal medical literature that ties low circulating levels of Pros1 to IBDs (Song et al. 2000; Zezos et al. 2007; Cakal et al. 2010; Diakou et al. 2011) and a much larger literature that establishes an association between low Pros1 and SLE (Song et al. 2000; Brouwer et al. 2004; Meesters et al. 2007). A recent analysis of a 107-patient SLE cohort found that levels of free protein S-but not Gas6-were significantly lower in SLE patients with a history of serositis, neurologic disorder, hematologic disorder, and immunologic disorder, and that low Pros1 levels were correlated with other disease-associated risk factors such as reductions in the complement proteins $\mathrm{C} 3$ and C4 (Suh et al. 2010). Polymorphisms in the Mertk gene have been tied to SLE (Cheong et al. 2007), and a clear genetic link has also been made with respect to the development of multiple sclerosis (MS). Here, a large genome-wide association study identified polymorphisms in the Mertk gene as risk factors for the development of MS (Ma et al. 2011; Sawcer et al. 2011).

The most widely prescribed drugs used to treat the chronic inflammation associated with many human autoimmune diseases-namely, glucocorticoids (GCs) such as prednisone and prednisolone-have recently been shown to potentiate TAM signaling. One well-described immunosuppressive activity of GCs is their ability to stimulate the phagocytosis of ACs by macrophages (Liu et al. 1999). Agonists for the liverX-receptor (LXR) family of nuclear hormone receptors display this same activity (A-Gonzalez et al. 2009). Remarkably, the ability of both GCs and LXR agonists to stimulate macrophage phagocytosis of ACs has recently been shown to be due entirely to their ability to up-regulate expression of Mer (A-Gonzalez et al. 2009; McColl et al. 2009). These and related findings suggest that activation of TAM signaling may be therapeutic in the context of autoimmune disease. In this regard, in vivo delivery of adenoviruses expressing either Gas6 or Pros1 has been found to significantly diminish disease symptoms in a mouse model of collagen-induced arthritis (van den Brand et al. 2013).

\section{TAM RECEPTORS AS TARGETS FOR VIRAL INFECTION}

A very active area of current research relates to the role of TAM receptors in infection by viruses. In a process termed "apoptotic mimicry" (Mercer and Helenius 2010; Mercer 2011), the eat-me signal PtdSer has been found to be displayed on the extracellular membrane surface of several enveloped viruses, including vaccinia virus, cytomegalovirus, Lassa fever virus, and HIV (Callahan et al. 2003; Mercer and Helenius 2008; Soares et al. 2008). In facilitating infection, the TAMs do not function as direct virus receptors. Rather, Gas6 and Pros1 again serve as "bridging molecules" - this time between a membrane that surrounds a virus capsid and the cell that the virus will infect (Fig. 1).

Tyro3, Axl, and Mer have been found to function as entry factors for the Ebola/Marburg family of hemorrhagic fever filoviruses (Shimojima et al. 2006, 2007). Closely related cell lines that show marked differences in infectivity with pseudotyped viruses containing Ebola or Marburg envelope glycoproteins, or in infectivity with the Zaire or Reston strains of bona fide Ebola, were distinguished principally by TAM expression. Lines with high levels of Axl and/ or Tyro3 were more readily infected than TAMnegative cells. Introduction of either Tyro 3 or Axl into filovirus-resistant cells rendered these cells susceptible to infection, and anti-Axl antibodies antagonized infection of Axl-expressing cells with MLV viruses pseudotyped with Ebola glycoprotein (Shimojima et al. 2006).

Similar results have been obtained using infection of endothelial cells with lentiviral vectors pseudotyped with Sindbis virus glycoproteins (Morizono et al. 2011). These experiments 
G. Lemke

also identified Gas6 and Pros1 as "bridging factors" that link PtdSer on the external surface of the viral envelope to Axl on the target cell. Depending on culture conditions, introduction of TAM cDNAs potentiated virus titers in infection-resistant cell lines $\geq 50$-fold. This has also recently been observed for infection by the Dengue (DENV) and West Nile viruses (WNV) of the flavivirus family (Meertens et al. 2012). An unbiased cDNA transfection screen in human $293 \mathrm{~T}$ cells, which are resistant to infection by these viruses, identified Tyro 3 and Axl as factors that greatly enhance infection. Consistent with the interaction model depicted in Figure 1 , this enhancement was found to be entirely dependent on the presence of a TAM ligand and also on the expression of PtdSer on the extracellular leaflet of the virus envelope (Meertens et al. 2012). In general, the above findings have been interpreted to suggest that TAM receptors serve as docking sites for TAM-ligand-bound virus particles. However, mutational analyses also indicate that tyrosine kinase activity is required for Axl potentiation of infection by Ebola (Shimojima et al. 2007) and DENV (Meertens et al. 2012), and thus active TAM signaling appears to be required for the potentiation of virus infection just as it is required for the phagocytosis of ACs. Given that (1) Axl activation potently suppresses type I IFN signaling in DCs and macrophages (Sharif et al. 2006; Rothlin et al. 2007; Shao et al. 2010), (2) type I IFNs are strong antiviral agents (Diamond 2003), and (3) suppression of type I IFN signaling is a mechanism that viruses exploit repeatedly as a means of immune evasion (Diamond 2003; Bonjardim et al. 2009; Versteeg and Garcia-Sastre 2010), the activation of TAM receptor signaling by viruses may prove to be an exceptionally effective mechanism of viral infection.

\section{TAM RECEPTORS AND CANCER}

There is a long association of TAM receptors with cancer-the first cDNAs for Axl and Mer were cloned from myeloid leukemia and lymphoblastoid lines, respectively (O'Bryan et al. 1991; Graham et al. 1994), and a truncated form of Mer (designated v-eyk) was identified initially as an avian retroviral oncogene (Jia et al. 1992; Jia and Hanafusa 1994). Axl was named from the Greek anexelekto, meaning "uncontrolled." Over the ensuing two decades, hundreds of papers have appeared that link TAM receptor and ligand expression to various forms of cancer (Linger et al. 2008; Verma et al. 2011). In general, these studies have reported overexpression or up-regulation of Axl, Mer, Tyro3, and/or Gas6. In many settings, however, a definitive demonstration that overexpression is causal for particular features of cancer development or progression has not been made. Elevated expression of TAM signaling components has been reported for leukemias (Graham et al. 1994, 2006; Hong et al. 2008), gliomas (Hutterer et al. 2008; Keating et al. 2010), colorectal carcinomas (Craven et al. 1995), breast cancers (Berclaz et al. 2001; Gjerdrum et al. 2010), gastrointestinal stromal tumors (Mahadevan et al. 2007), hepatocellular carcinoma (He et al. 2010), melanoma (Quong et al. 1994; Koorstra et al. 2009; Zhu et al. 2009), pancreatic adenocarcinoma (Song et al. 2010), and prostate cancer (Wu et al. 2004; Sainaghi et al. 2005), among several others.

Expression of Axl is correlated with an adverse prognosis in acute myeloid leukemia (Rochlitz et al. 1999), glioblastoma multiforme (Hutterer et al. 2008), pancreatic cancer (Koorstra et al. 2009), and esophageal adenocarcinoma (Hector et al. 2010). Axl up-regulation and activation have also been found to be a clinically significant feature of resistance to EGF receptor inhibitor and PI3K inhibitor therapies for nonsmall-cell lung cancer (Zhang et al. 2012; Byers et al. 2013). In many settings, Axl and/or Gas6 expression is most prominently associated with tumor metastasis, rather than growth of the primary tumor (Gjerdrum et al. 2010; Song et al. 2010). Consistent with this association, a smallmolecule inhibitor of the Axl tyrosine kinase has shown efficacy primarily with respect to a reduced metastatic burden, rather than primary tumor growth, in mouse models of breast cancer metastasis (Holland et al. 2010). The link between TAM receptor expression and tumor metastasis is interesting in light of the importance of Axl and Tyro3 in the migration of 
gonadotropin-releasing hormone (GnRH) neurons from the olfactory placode to hypothalamus of the brain (Allen et al. 2002a; Pierce et al. 2008). This migration of GnRH neurons involves Gas6 activation of the same downstream signaling pathways-PI3 kinase, ERK1/2, and Rac via Ras (Allen et al. 2002a,b; Nielsen-Preiss et al. 2007) — that are engaged downstream from TAMs in tumor cells.

\section{TAM REGULATION OF THE VASCULATURE SYSTEM}

TAM signaling plays an important role in the homeostatic regulation of blood vessel integrity and permeability. The TAM ligands Gas6 and Pros 1 were first identified in and purified from aortic endothelial cells (Stitt et al. 1995), and studies using conditional Pros1 knockouts have shown that vascular endothelial cells are a major source of the Pros1 that appears in the circulation (Burstyn-Cohen et al. 2009). Axl and Tyro 3 are also expressed by the vascular smooth muscle cells that surround these endothelia, and Gas6 and Pros1 have potent trophic effects on these cells, both in vitro and in vivo (Gasic et al. 1992; Fridell et al. 1998; Melaragno et al. 1999; Collett et al. 2007; Son et al. 2007; Cavet et al. 2008). The PI3 kinase/Akt pathway is again implicated as a key effector of TAM signaling in smooth muscle.

Damage to blood vessels results in the upregulation of both Axl and Gas6 (Melaragno et al. 1998), and a complex pattern of differential regulation of Axl, Mer, Gas6, and Pros1 has been reported in human atherosclerotic plaques (Hurtado et al.2011). Defects in the clearance of apoptotic cells from these plaques are linked to progression of advanced atherosclerotic lesions, and the role of compromised TAM signaling in cardiovascular disease is a subject of active study (Ait-Oufella et al. 2008; Thorp 2010). Pros $1^{+/-}$ mice with a 50\% reduction in Pros1 display vessel breaches, with leakage of blood into the parenchyma of tissues (Burstyn-Cohen et al. 2009). Pros1 has also been linked to vascular integrity in the brain. Pros1, signaling through Tyro3, has been implicated in maintenance of the blood-brain barrier and has been found to ameliorate hypoxic/ischemic blood-brain barrier disruption (Zhu et al. 2010).

In addition to these direct activities, TAM signaling has been shown to affect vascular integrity indirectly, through the regulation of platelet function. Loss of one or more TAM receptors has been observed to impair stabilization of platelet aggregates, at least in part by reducing platelet granule secretion. Gas6 activates $\mathrm{PI} 3 \mathrm{~K} /$ Akt signaling in platelets and stimulates tyrosine phosphorylation of $\beta 3$ integrin, thereby amplifying thrombus formation (AngelilloScherrer et al. 2001, 2005).

\section{PROSPECTS}

In addition to the biological settings outlined above, there is a significant body of literature to suggest that TAM signaling may play regulatory roles in the nervous system. Microglia, the tissue macrophages of the brain, also express Axl and Mer (Gautier et al. 2012), and there is evidence that TAM signaling through these receptors controls the phagocytosis of ACs and the inhibition of inflammation in the CNS just as it does in macrophages and DCs in the periphery (Grommes et al. 2008; Weinger et al. 2011). Tyro3 is also prominently expressed by many CNS neurons (Lai and Lemke 1991; Lai et al. 1994; Prieto et al. 2000, 2007). Its role in these neurons has for the most part remained obscure, however, and therefore this area is wide open for future study.

As noted at the outset, TAM receptor and ligand functions are, in the main, devoted to the homeostatic regulation of phenomena that are regular, cyclic, and circadian. These signaling proteins operate in adult, fully differentiated tissues that are subject to constant challenge and regular renewal. These features, together with the fact that the TAMs are RTKs expressed on the cell surface, make the TAM system a particularly favorable target for therapeutic intervention.

\section{REFERENCES}

A-Gonzalez N, Bensinger SJ, Hong C, Beceiro S, Bradley MN, Zelcer N, Deniz J, Ramirez C, Diaz M, Gallardo G, 
G. Lemke

et al. 2009. Apoptotic cells promote their own clearance and immune tolerance through activation of the nuclear receptor LXR. Immunity 31: 245-258.

Ait-Oufella H, Pouresmail V, Simon T, Blanc-Brude O, Kinugawa K, Merval R, Offenstadt G, Leseche G, Cohen PL, Tedgui A, et al. 2008. Defective mer receptor tyrosine kinase signaling in bone marrow cells promotes apoptotic cell accumulation and accelerates atherosclerosis. Arterioscler Thromb Vasc Biol 28: 1429-1431.

Akira S. 2006. TLR signaling. Curr Top Microbiol Immunol 311: $1-16$

Allen MP, Linseman DA, Udo H, Xu M, Schaack JB, Varnum B, Kandel ER, Heidenreich KA, Wierman ME. 2002a. Novel mechanism for gonadotropin-releasing hormone neuronal migration involving Gas6/Ark signaling to p38 mitogen-activated protein kinase. Mol Cell Biol 22: 599_ 613.

Allen MP, Xu M, Linseman DA, Pawlowski JE, Bokoch GM, Heidenreich KA, Wierman ME. 2002b. Adhesion-related kinase repression of gonadotropin-releasing hormone gene expression requires Rac activation of the extracellular signal-regulated kinase pathway. J Biol Chem 277: 38133-38140.

Angelillo-Scherrer A, de Frutos P, Aparicio C, Melis E, Savi P, Lupu F, Arnout J, Dewerchin M, Hoylaerts M, Herbert J, et al. 2001. Deficiency or inhibition of Gas6 causes platelet dysfunction and protects mice against thrombosis. Nat Med 7: 215-221.

Angelillo-Scherrer A, Burnier L, Flores N, Savi P, DeMol M, Schaeffer P, Herbert J-M, Lemke G, Goff SP, Matsushima GK, et al. 2005. Role of Gas6 receptors in platelet signaling during thrombus stabilization and implications for antithrombotic therapy. J Clin Invest 115: 237-246.

Arman E, Haffner-Krausz R, Chen Y, Heath JK, Lonai P. 1998. Targeted disruption of fibroblast growth factor (FGF) receptor 2 suggests a role for FGF signaling in pregastrulation mammalian development. Proc Natl Acad Sci 95: 5082-5087.

Bandyopadhyay PK. 2008. Vitamin K-dependent $\boldsymbol{\gamma}$-glutamylcarboxylation: An ancient posttranslational modification. Vitam Horm 78: 157-184.

Berclaz G, Altermatt HJ, Rohrbach V, Kieffer I, Dreher E, Andres AC. 2001. Estrogen dependent expression of the receptor tyrosine kinase axl in normal and malignant human breast. Ann Oncol 12: 819-824.

Beutler B, Jiang Z, Georgel P, Crozat K, Croker B, Rutschmann S, Du X, Hoebe K. 2006. Genetic analysis of host resistance: Toll-like receptor signaling and immunity at large. Annu Rev Immunol 24: 353-389.

Bonjardim CA, Ferreira PC, Kroon EG. 2009. Interferons: Signaling, antiviral and viral evasion. Immunol Lett 122: $1-11$.

Bourne MC, Campbell DA, Tansley K. 1938. Hereditary degeneration of the rat retina. $\mathrm{Br} J$ Ophthalmol 22: 613-623.

Braunger J, Schleithoff L, Schulz AS, Kessler H, Lammers R, Ullrich A, Bartram CR, Janssen JW. 1997. Intracellular signaling of the Ufo/Axl receptor tyrosine kinase is mediated mainly by a multi-substrate docking-site. Oncogene 14: 2619-2631.

Brouwer JL, Bijl M, Veeger NJ, Kluin-Nelemans HC, van der Meer J. 2004. The contribution of inherited and acquired thrombophilic defects, alone or combined with antiphospholipid antibodies, to venous and arterial thromboembolism in patients with systemic lupus erythematosus. Blood 104: 143-148.

Burstyn-Cohen T, Heeb MJ, Lemke G. 2009. Lack of protein $\mathrm{S}$ in mice causes embryonic lethal coagulopathy and vascular dysgenesis. J Clin Invest 119: 2942-2953.

Burstyn-Cohen T, Lew ED, Través PG, Burrola PG, Hash JC, Lemke G. 2012. Genetic dissection of TAM receptor-ligand interaction in retinal pigment epithelial cell phagocytosis. Neuron 76: 1123-1132.

Byers LA, Diao L, Wang J, Saintigny P, Girard L, Peyton M, Shen L, Fan Y, Giri U, Tumula PK, et al. 2013. An epithelial-mesenchymal transition gene signature predicts resistance to EGFR and PI3K inhibitors and identifies Axl as a therapeutic target for overcoming EGFR inhibitor resistance. Clin Cancer Res 19: 279-290.

Cakal B, Gokmen A, Yalinkilic M, Cakal E, Ayaz S, Nadir I, Ozin Y, Dagli U, Ulker A. 2010. Natural anticoagulant protein levels in Turkish patients with inflammatory bowel disease. Blood Coagul Fibrinolysis 21: 118-121.

Callahan MK, Popernack PM, Tsutsui S, Truong L, Schlegel RA, Henderson AJ. 2003. Phosphatidylserine on HIV envelope is a cofactor for infection of monocytic cells. J Immunol 170: 4840-4845.

Camenisch TD, Koller BH, Earp HS, Matsushima GK. 1999. A novel receptor tyrosine kinase, Mer, inhibits TNF- $\alpha$ production and lipopolysaccharide-induced endotoxic shock. J Immunol 162: 3498-3503.

Cavet ME, Smolock EM, Ozturk OH, World C, Pang J, Konishi A, Berk BC. 2008. Gas6-Axl receptor signaling is regulated by glucose in vascular smooth muscle cells. Arterioscler Thromb Vasc Biol 28: 886-891.

Chen J, Carey K, Godowski PJ. 1997. Identification of Gas6 as a ligand for Mer, a neural cell adhesion molecule related receptor tyrosine kinase implicated in cellular transformation. Oncogene 14: 2033-2039.

Chen Y, Wang H, Qi N, Wu H, Xiong W, Ma J, Lu Q, Han D. 2009. Functions of TAM RTKs in regulating spermatogenesis and male fertility in mice. Reproduction 138: 655-666.

Cheong HS, Lee SO, Choi CB, Sung YK, Shin HD, Bae SC. 2007. MERTK polymorphisms associated with risk of haematological disorders among Korean SLE patients. Rheumatology (Oxford) 46: 209-214.

Coleman JA, Kwok MC, Molday RS. 2009. Localization, purification, and functional reconstitution of the P4ATPase Atp8a2, a phosphatidylserine flippase in photoreceptor disc membranes. J Biol Chem 284: 3267032679.

Collett GD, Sage AP, Kirton JP, Alexander MY, Gilmore AP, Canfield AE. 2007. Axl/phosphatidylinositol 3-kinase signaling inhibits mineral deposition by vascular smooth muscle cells. Circ Res 100: 502-509.

Craven RJ, Xu LH, Weiner TM, Fridell YW, Dent GA, Srivastava S, Varnum B, Liu ET, Cance WG. 1995. Receptor tyrosine kinases expressed in metastatic colon cancer. Int J Cancer 60: 791-797.

Croker BA, Kiu H, Nicholson SE. 2008. SOCS regulation of the JAK/STAT signalling pathway. Semin Cell Dev Biol 19: $414-422$. 
Crosier PS, Lewis PM, Hall LR, Vitas MR, Morris CM, Beier DR, Wood CR, Crosier KE. 1994. Isolation of a receptor tyrosine kinase (DTK) from embryonic stem cells: Structure, genetic mapping and analysis of expression. Growth Factors 11: 125-136.

Dahlback B. 2000. Blood coagulation. Lancet 355: 1627 1632.

Dai W, Pan H, Hassanain H, Gupta SL, Murphy MJ Jr. 1994 Molecular cloning of a novel receptor tyrosine kinase, tif, highly expressed in human ovary and testis. Oncogene 9: $975-979$.

D'Cruz PM, Yasumura D, Weir J, Matthes MT, Abderrahim H, LaVail MM, Vollrath D. 2000. Mutation of the receptor tyrosine kinase gene Mertk in the retinal dystrophic RCS rat. Hum Mol Genet 9: 645-651.

Diakou M, Kostadima V, Giannopoulos S, Zikou AK, Argyropoulou MI, Kyritsis AP. 2011. Cerebral venous thrombosis in an adolescent with ulcerative colitis. Brain Dev 33: 49-51.

Diamond MS. 2003. Evasion of innate and adaptive immunity by flaviviruses. Immunol Cell Biol 81: 196-206.

Duncan HJ, LaVail MM, Yasumura D, Matthes MT, Yang H, Trautmann N, Chappelow AV, Feng W, Earp HS, Matsushima GK, et al. 2003. An RCS-like retinal dystrophy phenotype in mer knockout mice. Invest Ophthalmol Visual Sci 44: 826-838.

Edwards RB, Szamier RB. 1977. Defective phagocytosis of isolated rod outer segments by RCS rat retinal pigment epithelium in culture. Science 197: 1001-1003.

Ekman C, Stenhoff J, Dahlback B. 2010. Gas6 is complexed to the soluble tyrosine kinase receptor Axl in human blood. J Thromb Haemost 8: 838-844.

Elliott MR, Ravichandran KS. 2010. Clearance of apoptotic cells: Implications in health and disease. J Cell Biol 189: 1059- 1070.

Evenas P, Dahlback B, Garcia de Frutos P. 2000. The first laminin G-type domain in the SHBG-like region of protein $S$ contains residues essential for activation of the receptor tyrosine kinase sky. Biol Chem 381: 199-209.

Feng W, Yasumura D, Matthes MT, LaVail MM, Vollrath D. 2002. Mertk triggers uptake of photoreceptor outer segments during phagocytosis by cultured retinal pigment epithelial cells. J Biol Chem 277: 17016-17022.

Fridell YW, Jin Y, Quilliam LA, Burchert A, McCloskey P, Spizz G, Varnum B, Der C, Liu ET. 1996. Differential activation of the Ras/extracellular-signal-regulated protein kinase pathway is responsible for the biological consequences induced by the Axl receptor tyrosine kinase. Mol Cell Biol 16: 135-145.

Fridell YW, Villa J Jr, Attar EC, Liu ET. 1998. GAS6 induces Axl-mediated chemotaxis of vascular smooth muscle cells. J Biol Chem 273: 7123-7126.

Fujimoto J, Yamamoto T. 1994. brt, a mouse gene encoding a novel receptor-type protein-tyrosine kinase, is preferentially expressed in the brain. Oncogene 9: 693-698.

Gaipl US, Munoz LE, Grossmayer G, Lauber K, Franz S, Sarter K, Voll RE, Winkler T, Kuhn A, Kalden J, et al. 2007. Clearance deficiency and systemic lupus erythematosus (SLE). J Autoimmun 28: 114-121.

Gal A, Li Y, Thompson DA, Weir J, Orth U, Jacobson SG, Apfelstedt-Sylla E, Vollrath D. 2000. Mutations in
MERTK, the human orthologue of the RCS rat retinal dystrophy gene, cause retinitis pigmentosa. Nat Genet 26: $270-271$.

Gasic GP, Arenas CP, Gasic TB, Gasic GJ. 1992. Coagulation factors $\mathrm{X}, \mathrm{Xa}$, and protein $\mathrm{S}$ as potent mitogens of cultured aortic smooth muscle cells. Proc Natl Acad Sci 89: 2317-2320.

Gassmann M, Casagranda F, Orioli D, Simon H, Lai C, Klein R, Lemke G. 1995. Aberrant neural and cardiac development in mice lacking the ErbB4 neuregulin receptor. Nature 378: 390-394.

Gautier EL, Shay T, Miller J, Greter M, Jakubzick C, Ivanov S, Helft J, Chow A, Elpek KG, Gordonov S, et al. 2012. Gene-expression profiles and transcriptional regulatory pathways that underlie the identity and diversity of mouse tissue macrophages. Nat Immunol 13: 1118-1128.

Georgescu MM, Kirsch KH, Shishido T, Zong C, Hanafusa H. 1999. Biological effects of c-Mer receptor tyrosine kinase in hematopoietic cells depend on the Grb2 binding site in the receptor and activation of NF-кB. Mol Cell Biol 19: 1171-1181.

Gjerdrum C, Tiron C, Hoiby T, Stefansson I, Haugen H, Sandal T, Collett K, Li S, McCormack E, Gjertsen BT, et al. 2010. Axl is an essential epithelial-to-mesenchymal transition-induced regulator of breast cancer metastasis and patient survival. Proc Natl Acad Sci 107: 1124-1129.

Goruppi S, Ruaro E, Varnum B, Schneider C. 1997. Requirement of phosphatidylinositol 3-kinase-dependent pathway and Src for Gas6-Axl mitogenic and survival activities in NIH 3T3 fibroblasts. Mol Cell Biol 17: 4442-4453.

Graham DK, Dawson TL, Mullaney DL, Snodgrass HR, Earp HS. 1994. Cloning and mRNA expression analysis of a novel human protooncogene, $c$-mer. Cell Growth Differ 5: 647-657.

Graham DK, Salzberg DB, Kurtzberg J, Sather S, Matsushima GK, Keating AK, Liang X, Lovell MA, Williams SA, Dawson TL, et al. 2006. Ectopic expression of the protooncogene $\mathrm{Mer}$ in pediatric T-cell acute lymphoblastic leukemia. Clin Cancer Res 12: 2662-2669.

Grommes C, Lee CY, Wilkinson BL, Jiang Q, Koenigsknecht-Talboo JL, Varnum B, Landreth GE. 2008. Regulation of microglial phagocytosis and inflammatory gene expression by Gas6 acting on the Axl/Mer family of tyrosine kinases. J Neuroimmune Pharmacol 3: 130-140.

He L, Zhang J, Jiang L, Jin C, Zhao Y, Yang G, Jia L. 2010. Differential expression of Axl in hepatocellular carcinoma and correlation with tumor lymphatic metastasis. Mol Carcinog 49: 882-891.

Hector A, Montgomery EA, Karikari C, Canto M, Dunbar KB, Wang JS, Feldmann G, Hong SM, Haffner MC, Meeker AK, et al. 2010. The Axl receptor tyrosine kinase is an adverse prognostic factor and a therapeutic target in esophageal adenocarcinoma. Cancer Biol Ther 10: 10091018.

Heiring C, Dahlback B, Muller YA. 2004. Ligand recognition and homophilic interactions in Tyro3: Structural insights into the Axl/Tyro3 receptor tyrosine kinase family. J Biol Chem 279: 6952-6958.

Holland SJ, Pan A, Franci C, Hu Y, Chang B, Li W, Duan M, Torneros A, Yu J, Heckrodt TJ, et al. 2010. R428, a selective small molecule inhibitor of Axl kinase, blocks 
G. Lemke

tumor spread and prolongs survival in models of metastatic breast cancer. Cancer Res 70: 1544-1554.

Hong CC, Lay JD, Huang JS, Cheng AL, Tang JL, Lin MT, Lai GM, Chuang SE. 2008. Receptor tyrosine kinase AXL is induced by chemotherapy drugs and overexpression of AXL confers drug resistance in acute myeloid leukemia. Cancer Lett 268: 314-324.

Huang M, Rigby AC, Morelli X, Grant MA, Huang G, Furie B, Seaton B, Furie BC. 2003. Structural basis of membrane binding by Gla domains of vitamin K-dependent proteins. Nat Struct Biol 10: 751-756.

Huang X, Finerty P Jr, Walker JR, Butler-Cole C, Vedadi M, Schapira M, Parker SA, Turk BE, Thompson DA, DhePaganon S. 2009. Structural insights into the inhibited states of the Mer receptor tyrosine kinase. J Struct Biol 165: $88-96$.

Hurtado B, Munoz X, Recarte-Pelz P, Garcia N, Luque A Krupinski J, Sala N, Garcia de Frutos P. 2011. Expression of the vitamin K-dependent proteins GAS6 and protein S and the TAM receptor tyrosine kinases in human atherosclerotic carotid plaques. Thromb Haemost 105: $873-$ 882.

Hutterer M, Knyazev P, Abate A, Reschke M, Maier H, Stefanova N, Knyazeva T, Barbieri V, Reindl M, Muigg A, et al. 2008. Axl and growth arrest-specific gene 6 are frequently overexpressed in human gliomas and predict poor prognosis in patients with glioblastoma multiforme. Clin Cancer Res 14: 130-138.

Ishimoto Y, Ohashi K, Mizuno K, Nakano T. 2000. Promotion of the uptake of PS liposomes and apoptotic cells by a product of growth arrest-specific gene, gas6. J Biochem 127: 411-417.

Iwasaki A, Medzhitov R. 2004. Toll-like receptor control of the adaptive immune responses. Nat Immunol 5: 987995.

Janssen JW, Schulz AS, Steenvoorden AC, Schmidberger M, Strehl S, Ambros PF, Bartram CR. 1991. A novel putative tyrosine kinase receptor with oncogenic potential. Oncogene 6: 2113-2120.

Jia R, Hanafusa H. 1994. The proto-oncogene of v-eyk $(v-r y k)$ is a novel receptor-type protein tyrosine kinase with extracellular Ig/GN-III domains. J Biol Chem 269: 1839-1844.

Jia R, Mayer BJ, Hanafusa T, Hanafusa H. 1992. A novel oncogene, $v$-ryk, encoding a truncated receptor tyrosine kinase is transduced into the RPL30 virus without loss of viral sequences. J Virol 66: 5975-5987.

Kawasaki Y, Nakagawa A, Nagaosa K, Shiratsuchi A, Nakanishi Y. 2002. Phosphatidylserine binding of class B scavenger receptor type $\mathrm{I}$, a phagocytosis receptor of testicular sertoli cells. J Biol Chem 277: 27559-27566.

Keating AK, Kim GK, Jones AE, Donson AM, Ware K, Mulcahy JM, Salzberg DB, Foreman NK, Liang X, Thorburn A, et al. 2010. Inhibition of Mer and Axl receptor tyrosine kinases in astrocytoma cells leads to increased apoptosis and improved chemosensitivity. Mol Cancer Ther 9: 1298-1307.

Koorstra JB, Karikari CA, Feldmann G, Bisht S, Rojas PL, Offerhaus GJ, Alvarez H, Maitra A. 2009. The Axl receptor tyrosine kinase confers an adverse prognostic influence in pancreatic cancer and represents a new therapeutic target. Cancer Biol Ther 8: 618-626.
Kulman JD, Harris JE, Nakazawa N, Ogasawara M, Satake M, Davie EW. 2006. Vitamin K-dependent proteins in Ciona intestinalis, a basal chordate lacking a blood coagulation cascade. Proc Natl Acad Sci 103: 15794-15799.

Lai C, Lemke G. 1991. An extended family of protein-tyrosine kinase genes differentially expressed in the vertebrate nervous system. Neuron 6: 691-704.

Lai C, Gore M, Lemke G. 1994. Structure, expression, and activity of Tyro 3, a neural adhesion-related receptor tyrosine kinase. Oncogene 9: 2567-2578.

Lan Z, Wu H, Li W, Wu S, Lu L, Xu M, Dai W. 2000. Transforming activity of receptor tyrosine kinase Tyro3 is mediated, at least in part, by the PI3 kinase-signaling pathway. Blood 95: 633-638.

Lee KF, Simon H, Chen H, Bates B, Hung MC, Hauser C. 1995. Requirement for neuregulin receptor erbB2 in neural and cardiac development. Nature 378: 394-398.

Lemke G, Burstyn-Cohen T. 2010. TAM receptors and the clearance of apoptotic cells. Ann NY Acad Sci 1209: 23-29.

Lemke G, Rothlin CV. 2008. Immunobiology of the TAM receptors. Nat Rev Immunol 8: 327-336.

Li T, Chang CY, Jin DY, Lin PJ, Khvorova A, Stafford DW. 2004. Identification of the gene for vitamin $\mathrm{K}$ epoxide reductase. Nature 427: 541-544.

Lijnen HR, Christiaens V, Scroyen L. 2011. Growth arrestspecific protein 6 receptor antagonism impairs adipocyte differentiation and adipose tissue development in mice. J Pharmacol Exp Ther 337: 457-464.

Ling L, Kung HJ. 1995. Mitogenic signals and transforming potential of Nyk, a newly identified neural cell adhesion molecule-related receptor tyrosine kinase. Mol Cell Biol 15: 6582-6592.

Ling L, Templeton D, Kung HJ. 1996. Identification of the major autophosphorylation sites of $\mathrm{Nyk} / \mathrm{Mer}$, an NCAM-related receptor tyrosine kinase. J Biol Chem 271: $18355-18362$.

Linger RM, Keating AK, Earp HS, Graham DK. 2008. TAM receptor tyrosine kinases: Biologic functions, signaling, and potential therapeutic targeting in human cancer. Adv Cancer Res 100: 35-83.

Liu Y, Cousin JM, Hughes J, Van Damme J, Seckl JR, Haslett C, Dransfield I, Savill J, Rossi AG. 1999. Glucocorticoids promote nonphlogistic phagocytosis of apoptotic leukocytes. J Immunol 162: 3639-3646.

Liu J, Yang C, Simpson C, Deryckere D, Van Deusen A, Miley MJ, Kireev D, Norris-Drouin J, Sather S, Hunter D, et al. 2012. Discovery of novel small molecule Mer kinase inhibitors for the treatment of pediatric acute lymphoblastic leukemia. ACS Med Chem Lett 3: 129-134.

Lu Q, Lemke G. 2001. Homeostatic regulation of the immune system by receptor tyrosine kinases of the Tyro 3 family. Science 293: 306-311.

Lu Q, Gore M, Zhang Q, Camenisch T, Boast S, Casagranda F, Lai C, Skinner MK, Klein R, Matsushima GK, et al. 1999. Tyro-3 family receptors are essential regulators of mammalian spermatogenesis. Nature 398: 723-728.

Ma GZ, Stankovich J, Kilpatrick TJ, Binder MD, Field J. 2011. Polymorphisms in the receptor tyrosine kinase MERTK gene are associated with multiple sclerosis susceptibility. PLoS ONE 6: e16964. 
Mahadevan D, Cooke L, Riley C, Swart R, Simons B, Della Croce K, Wisner L, Iorio M, Shakalya K, Garewal H, et al. 2007. A novel tyrosine kinase switch is a mechanism of imatinib resistance in gastrointestinal stromal tumors. Oncogene 26: 3909-3919.

Mahajan NP, Earp HS. 2003. An SH2 domain-dependent, phosphotyrosine-independent interaction between Vavl and the Mer receptor tyrosine kinase: A mechanism for localizing guanine nucleotide-exchange factor action. J Biol Chem 278: 42596-42603.

Manfioletti G, Brancolini C, Avanzi G, Schneider C. 1993. The protein encoded by a growth arrest-specific gene (gas6) is a new member of the vitamin K-dependent proteins related to protein $S$, a negative coregulator in the blood coagulation cascade. Mol Cell Biol 13: $4976-$ 4985.

Manning G, Plowman GD, Hunter T, Sudarsanam S. 2002a. Evolution of protein kinase signaling from yeast to man. Trends Biochem Sci 27: 514-520.

Manning G, Whyte DB, Martinez R, Hunter T, Sudarsanam S. 2002b. The protein kinase complement of the human genome. Science 298: 1912-1934.

Mark MR, Scadden DT, Wang Z, Gu Q, Goddard A, Godowski PJ. 1994. rse, a novel receptor-type tyrosine kinase with homology to $\mathrm{Axl} / \mathrm{Ufo}$, is expressed at high levels in the brain. J Biol Chem 269: 10720-10728.

Mark MR, Chen J, Hammonds RG, Sadick M, Godowsk PJ. 1996. Characterization of Gas6, a member of the superfamily of $\mathrm{G}$ domain-containing proteins, as a ligand for Rse and Axl. J Biol Chem 271: 9785-9789.

Marshak-Rothstein A. 2006. Toll-like receptors in systemic autoimmune disease. Nat Rev Immunol 6: 823-835.

McColl A, Bournazos S, Franz S, Perretti M, Morgan BP, Haslett C, Dransfield I. 2009. Glucocorticoids induce protein S-dependent phagocytosis of apoptotic neutrophils by human macrophages. J Immunol 183: 21672175.

Meertens L, Carnec X, Lecoin MP, Ramdasi R, Guivel-Benhassine F, Lew E, Lemke G, Schwartz O, Amara A. 2012. The TIM and TAM families of phosphatidylserine receptors mediate Dengue virus entry. Cell Host Microbe 12: 544-557.

Meesters EW, Hansen H, Spronk HM, Hamulyak K, Rosing J, Rowshani AT, ten Berge IJ, ten Cate H. 2007. The inflammation and coagulation cross-talk in patients with systemic lupus erythematosus. Blood Coagul Fibrinolysis 18: $21-28$.

Melaragno MG, Wuthrich DA, Poppa V, Gill D, Lindner V, Berk BC, Corson MA. 1998. Increased expression of Axl tyrosine kinase after vascular injury and regulation by $\mathrm{G}$ protein-coupled receptor agonists in rats. Circ Res 83: 697-704.

Melaragno MG, Fridell YW, Berk BC. 1999. The Gas6/Axl system: A novel regulator of vascular cell function. Trends Cardiovasc Med 9: 250-253.

Mercer J. 2011. Viral apoptotic mimicry party: P.S. Bring your own Gas6. Cell Host Microbe 9: 255-257.

Mercer J, Helenius A. 2008. Vaccinia virus uses macropinocytosis and apoptotic mimicry to enter host cells. Science 320: $531-535$.
Mercer J, Helenius A. 2010. Apoptotic mimicry: Phosphatidylserine-mediated macropinocytosis of vaccinia virus. Ann NY Acad Sci 1209: 49-55.

Ming Cao W, Murao K, Imachi H, Sato M, Nakano T, Kodama T, Sasaguri Y, Wong NC, Takahara J, Ishida T. 2001. Phosphatidylinositol 3-OH kinase-Akt/protein kinase B pathway mediates Gas6 induction of scavenger receptor A in immortalized human vascular smooth muscle cell line. Arterioscler Thromb Vasc Biol 21: 1592-1597.

Morizono K, Xie Y, Olafsen T, Lee B, Dasgupta A, Wu AM, Chen IS. 2011. The soluble serum protein Gas6 bridges virion envelope phosphatidylserine to the TAM receptor tyrosine kinase Axl to mediate viral entry. Cell Host Microbe 9: $286-298$.

Nagata K, Ohashi K, Nakano T, Arita H, Zong C, Hanafusa H, Mizuno K. 1996. Identification of the product of growth arrest-specific gene 6 as a common ligand for Axl, Sky, and Mer receptor tyrosine kinases. J Biol Chem 271: 30022-30027.

Nagata S, Hanayama R, Kawane K. 2010. Autoimmunity and the clearance of dead cells. Cell 140: 619-630.

Nandrot EF, Dufour EM. 2010. Mertk in daily retinal phagocytosis: A history in the making. Adv Exp Med Biol 664: 133-140.

Nielsen-Preiss SM, Allen MP, Xu M, Linseman DA, Pawlowski JE, Bouchard RJ, Varnum BC, Heidenreich KA, Wierman ME. 2007. Adhesion-related kinase induction of migration requires phosphatidylinositol-3-kinase and Ras stimulation of Rac activity in immortalized gonadotropin-releasing hormone neuronal cells. Endocrinology 148: $2806-2814$

Nyberg P, He X, Hardig Y, Dahlback B, Garcia de Frutos P. 1997. Stimulation of Sky tyrosine phosphorylation by bovine protein $\mathrm{S}$-domains involved in the receptor-ligand interaction. Eur J Biochem 246: 147-154.

O'Bryan JP, Frye RA, Cogswell PC, Neubauer A, Kitch B, Prokop C, Espinosa R III, Le Beau MM, Earp HS, Liu ET. 1991. axl, a transforming gene isolated from primary human myeloid leukemia cells, encodes a novel receptor tyrosine kinase. Mol Cell Biol 11: 5016-5031.

Ohashi K, Mizuno K, Kuma K, Miyata T, Nakamura T. 1994. Cloning of the cDNA for a novel receptor tyrosine kinase, Sky, predominantly expressed in brain. Oncogene 9: 699705.

Ohashi K, Nagata K, Toshima J, Nakano T, Arita H, Tsuda H, Suzuki K, Mizuno K. 1995. Stimulation of sky receptor tyrosine kinase by the product of growth arrest-specific gene 6. J Biol Chem 270: 22681-22684.

Ostergaard E, Duno M, Batbayli M, Vilhelmsen K, Rosenberg T. 2011. A novel MERTK deletion is a common founder mutation in the Faroe Islands and is responsible for a high proportion of retinitis pigmentosa cases. $\mathrm{Mol}$ Vis 17: 1485-1492.

Ou WB, Corson JM, Flynn DL, Lu WP, Wise SC, Bueno R, Sugarbaker DJ, Fletcher JA. 2011. AXL regulates mesothelioma proliferation and invasiveness. Oncogene 30: $1643-1652$.

Pierce A, Bliesner B, Xu M, Nielsen-Preiss S, Lemke G, Tobet S, Wierman ME. 2008. Axl and Tyro3 modulate female reproduction by influencing gonadotropin-releasing hormone neuron survival and migration. Mol Endocrinol 22: 2481-2495. 
G. Lemke

Powell NA, Kohrt JT, Filipski KJ, Kaufman M, Sheehan D, Edmunds JE, Delaney A, Wang Y, Bourbonais F, Lee DY, et al. 2012. Novel and selective spiroindoline-based inhibitors of Sky kinase. Bioorg Med Chem Lett 22: 190-193.

Prasad D, Rothlin CV, Burrola P, Burstyn-Cohen T, Lu Q, Garcia de Frutos P, Lemke G. 2006. TAM receptor function in the retinal pigment epithelium. Mol Cell Neurosci 33: $96-108$.

Prieto AL, Weber JL, Lai C. 2000. Expression of the receptor protein-tyrosine kinases Tyro-3, Axl, and Mer in the developing rat central nervous system. J Comp Neurol 425: 295-314.

Prieto AL, O’Dell S, Varnum B, Lai C. 2007. Localization and signaling of the receptor protein tyrosine kinase Tyro3 in cortical and hippocampal neurons. Neuroscience 150: 319-334.

Quong RY, Bickford ST, Ing YL, Terman B, Herlyn M, Lassam NJ. 1994. Protein kinases in normal and transformed melanocytes. Melanoma Res 4: 313-319.

Radic MZ, Shah K, Lu Q, Lemke G, Hillard GM. 2006 Heterogeneous nuclear ribonucleoprotein P2 is an autoantibody target in mice deficient for Mer, Axl, and Tyro3 receptor tyrosine kinases. J Immunology 176: 68-74.

Rajotte I, Hasanbasic I, Blostein M. 2008. Gas6-mediated signaling is dependent on the engagement of its $\gamma$ carboxyglutamic acid domain with phosphatidylserine. Biochem Biophys Res Commun 376: 70-73.

Ravichandran KS. 2010. Find-me and eat-me signals in apoptotic cell clearance: Progress and conundrums. J Exp Med 207: 1807-1817.

Rescigno J, Mansukhani A, Basilico C. 1991. A putative receptor tyrosine kinase with unique structural topology. Oncogene 6: 1909-1913.

Rochlitz C, Lohri A, Bacchi M, Schmidt M, Nagel S, Fopp M, Fey MF, Herrmann R, Neubauer A. 1999. Axl expression is associated with adverse prognosis and with expression of Bcl-2 and CD34 in de novo acute myeloid leukemia (AML): Results from a multicenter trial of the Swiss Group for Clinical Cancer Research (SAKK). Leukemia 13: $1352-1358$.

Ronnblom L, Pascual V. 2008. The innate immune system in SLE: Type I interferons and dendritic cells. Lupus 17: 394-399.

Rothlin CV, Lemke G. 2010. TAM receptor signaling and autoimmune disease. Curr Opin Immunol 22: 740-746.

Rothlin CV, Ghosh S, Zuniga EI, Oldstone MB, Lemke G. 2007. TAM receptors are pleiotropic inhibitors of the innate immune response. Cell 131: 1124-1136.

Sainaghi PP, Castello L, Bergamasco L, Galletti M, Bellosta P, Avanzi GC. 2005. Gas6 induces proliferation in prostate carcinoma cell lines expressing the Axl receptor. J Cell Physiol 204: 36-44.

Sasaki T, Knyazev PG, Cheburkin Y, Gohring W, Tisi D, Ullrich A, Timpl R, Hohenester E. 2002. Crystal structure of a C-terminal fragment of growth arrest-specific protein Gas6. Receptor tyrosine kinase activation by laminin G-like domains. J Biol Chem 277: 44164-44170.

Sasaki T, Knyazev PG, Clout NJ, Cheburkin Y, Gohring W, Ullrich A, Timpl R, Hohenester E. 2006. Structural basis for Gas6-Axl signalling. EMBO J 25: 80-87.
Sawcer S, Hellenthal G, Pirinen M, Spencer CC, Patsopoulos NA, Moutsianas L, Dilthey A, Su Z, Freeman C, Hunt SE, et al. 2011. Genetic risk and a primary role for cell-mediated immune mechanisms in multiple sclerosis. Nature 476: $214-219$.

Scott RS, McMahon EJ, Pop SM, Reap EA, Caricchio R, Cohen PL, Earp HS, Matsushima GK. 2001. Phagocytosis and clearance of apoptotic cells is mediated by MER. Nature 411: 207-211.

Seitz HM, Camenisch TD, Lemke G, Earp HS, Matsushima GK. 2007. Macrophages and dendritic cells use different Axl/Mertk/Tyro3 receptors in clearance of apoptotic cells. J Immunol 178: 5635-5642.

Shao WH, Cohen PL. 2011. Disturbances of apoptotic cell clearance in systemic lupus erythematosus. Arthritis Res Ther 13: 202.

Shao WH, Zhen Y, Eisenberg RA, Cohen PL. 2009. The Mer receptor tyrosine kinase is expressed on discrete macrophage subpopulations and mainly uses Gas6 as its ligand for uptake of apoptotic cells. Clin Immunol 133: $138-$ 144.

Shao WH, Kuan AP, Wang C, Abraham V, Waldman MA, Vogelgesang A, Wittenburg G, Choudhury A, Tsao PY, Miwa T, et al. 2010. Disrupted Mer receptor tyrosine kinase expression leads to enhanced MZ B-cell responses. J Autoimmun 35: 368-374.

Sharif MN, Sosic D, Rothlin CV, Kelly E, Lemke G, Olson EN, Ivashkiv LB. 2006. Twist mediates suppression of inflammation by type I IFNs and Ax1. J Exp Med 203: 1891-1901.

Shimojima M, Takada A, Ebihara H, Neumann G, Fujioka K, Irimura T, Jones S, Feldmann H, Kawaoka Y. 2006. Tyro3 family-mediated cell entry of Ebola and Marburg viruses. J Virol 80: 10109-10116.

Shimojima M, Ikeda Y, Kawaoka Y. 2007. The mechanism of Axl-mediated Ebola virus infection. J Infect Dis 196: S259-263.

Smiley ST, Boyer SN, Heeb MJ, Griffin JH, Grusby MJ. 1997. Protein $S$ is inducible by interleukin 4 in T cells and inhibits lymphoid cell procoagulant activity. Proc Natl Acad Sci 94: 11484-11489.

Soares MM, King SW, Thorpe PE. 2008. Targeting insideout phosphatidylserine as a therapeutic strategy for viral diseases. Nat Med 14: 1357-1362.

Son BK, Kozaki K, Iijima K, Eto M, Nakano T, Akishita M, Ouchi Y. 2007. Gas6/Axl-PI3K/Akt pathway plays a central role in the effect of statins on inorganic phosphateinduced calcification of vascular smooth muscle cells. Eur J Pharmacol 556: 1-8.

Song KS, Park YS, Kim HK. 2000. Prevalence of anti-protein $S$ antibodies in patients with systemic lupus erythematosus. Arthritis Rheum 43: 557-560.

Song X, Wang H, Logsdon CD, Rashid A, Fleming JB, Abbruzzese JL, Gomez HF, Evans DB. 2010. Overexpression of receptor tyrosine kinase Axl promotes tumor cell invasion and survival in pancreatic ductal adenocarcinoma. Cancer 117: 734-743.

Soriano P. 1997. The PDGF $\alpha$ receptor is required for neural crest cell development and for normal patterning of the somites. Development 124: 2691-2700. 
Sparrow JR, Hicks D, Hamel CP. 2010. The retinal pigment epithelium in health and disease. Curr Mol Med 10: 802823.

Stafford DW. 2005. The vitamin K cycle. J Thromb Haemost 3: $1873-1878$.

Stitt TN, Conn G, Gore M, Lai C, Bruno J, Radziejewski C, Mattsson K, Fisher J, Gies DR, Jones PF, et al. 1995. The anticoagulation factor protein $S$ and its relative, Gas6, are ligands for the Tyro 3/Axl family of receptor tyrosine kinases. Cell 80: 661-670.

Strick DJ, Feng W, Vollrath D. 2009. Mertk drives myosin II redistribution during retinal pigment epithelial phagocytosis. Invest Ophthalmol Vis Sci 50: 2427-2435.

Suh CH, Hilliard B, Li S, Merrill JT, Cohen PL. 2010. TAM receptor ligands in lupus: Protein S but not Gas6 levels reflect disease activity in systemic lupus erythematosus. Arthritis Res Ther 12: R146.

Sun B, Qi N, Shang T, Wu H, Deng T, Han D. 2010. Sertol cell-initiated testicular innate immune response through Toll-like receptor-3 activation is negatively regulated by Tyro3, Axl, and Mer receptors. Endocrinology 151: $2886-$ 2897.

Tanabe K, Nagata K, Ohashi K, Nakano T, Arita H, Mizuno K. 1997. Roles of $\gamma$-carboxylation and a sex hormonebinding globulin-like domain in receptor-binding and in biological activities of Gas6. FEBS Lett 408: 306-310.

Thorp EB. 2010. Mechanisms of failed apoptotic cell clearance by phagocyte subsets in cardiovascular disease. Apoptosis 15: 1124-1136.

Thorp E, Cui D, Schrijvers DM, Kuriakose G, Tabas I. 2008. Mertk receptor mutation reduces efferocytosis efficiency and promotes apoptotic cell accumulation and plaque necrosis in atherosclerotic lesions of $A p o e^{-/-}$mice. Arterioscler Thromb Vasc Biol 28: 1421-1428.

Tibrewal N, Wu Y, D’Mello V, Akakura R, George TC, Varnum B, Birge RB. 2008. Autophosphorylation docking site Tyr-867 in Mer receptor tyrosine kinase allows for dissociation of multiple signaling pathways for phagocytosis of apoptotic cells and down-modulation of lipopolysaccharide-inducible NF- $\kappa \mathrm{B}$ transcriptional activation. J Biol Chem 283: 3618-3627.

Todt JC, Hu B, Curtis JL. 2008. The scavenger receptor SR-A I/II (CD204) signals via the receptor tyrosine kinase Mertk during apoptotic cell uptake by murine macrophages. J Leukoc Biol 84: 510-518.

Uehara H, Shacter E. 2008. Auto-oxidation and oligomerization of protein $S$ on the apoptotic cell surface is required for Mer tyrosine kinase-mediated phagocytosis of apoptotic cells. J Immunol 180: 2522-2530.

van den Brand BT, Abdollahi-Roodsaz S, Vermeij EA, Bennink MB, Arntz OJ, Rothlin CV, van den Berg WB, van de Loo FA. 2013. Therapeutic efficacy of Tyro3, Axl, and Mer tyrosine kinase agonists in collagen-induced arthritis. Arthritis Rheum 65: 671-680.

van Meer G, Voelker DR, Feigenson GW. 2008. Membrane lipids: Where they are and how they behave. Nat Rev Mol Cell Biol 9: 112-124.

Verma A, Warner SL, Vankayalapati H, Bearss DJ, Sharma S. 2011. Targeting Axl and Mer kinases in cancer. Mol Cancer Ther 10: 1763-1773.
Versteeg GA, Garcia-Sastre A. 2010. Viral tricks to grid-lock the type I interferon system. Curr Opin Microbiol 13: 508-516.

Wallet MA, Sen P, Flores RR, Wang Y, Yi Z, Huang Y, Mathews CE, Earp HS, Matsushima G, Wang B, et al. 2008. MerTK is required for apoptotic cell-induced $T$ cell tolerance. J Exp Med 205: 219-232.

Weinger JG, Gohari P, Yan Y, Backer JM, Varnum B, ShafitZagardo B. 2008. In brain, Axl recruits Grb2 and the p85 regulatory subunit of PI3 kinase; in vitro mutagenesis defines the requisite binding sites for downstream Akt activation. J Neurochem 106: 134-146.

Weinger JG, Brosnan CF, Loudig O, Goldberg MF, Macian F, Arnett HA, Prieto AL, Tsiperson V, Shafit-Zagardo B. 2011. Loss of the receptor tyrosine kinase Axl leads to enhanced inflammation in the CNS and delayed removal of myelin debris during experimental autoimmune encephalomyelitis. J Neuroinflammation 8: 49.

Wu YM, Robinson DR, Kung HJ. 2004. Signal pathways in up-regulation of chemokines by tyrosine kinase MER/ NYK in prostate cancer cells. Cancer Res 64: 7311-7320.

Wu Y, Tibrewal N, Birge RB. 2006. Phosphatidylserine recognition by phagocytes: A view to a kill. Trends Cell Biol 16: 189-197.

Ye F, Han L, Lu Q, Dong W, Chen Z, Shao H, Kaplan HJ, Li Q. 2011. Retinal self-antigen induces a predominantly Th1 effector response in Axl and Mertk double-knockout mice. J Immunol 187: 4178-4186.

Yoshimura A, Naka T, Kubo M. 2007. SOCS proteins, cytokine signalling and immune regulation. Nat Rev Immunol 7: 454-465.

Zezos P, Papaioannou G, Nikolaidis N, Vasiliadis T, Giouleme O, Evgenidis N. 2007. Thrombophilic abnormalities of natural anticoagulants in patients with ulcerative colitis. Hepatogastroenterology 54: 1417-1421.

Zhang Z, Lee JC, Lin L, Olivas V, Au V, LaFramboise T, Abdel-Rahman $\mathrm{M}$, Wang $\mathrm{X}$, Levine $\mathrm{AD}$, Rho JK, et al. 2012. Activation of the AXL kinase causes resistance to EGFR-targeted therapy in lung cancer. Nat Genet 44: $852-860$.

Zhong Z, Wang Y, Guo H, Sagare A, Fernandez JA, Bell RD, Barrett TM, Griffin JH, Freeman RS, Zlokovic BV. 2010. Protein $\mathrm{S}$ protects neurons from excitotoxic injury by activating the TAM receptor Tyro3-phosphatidylinositol 3-kinase-Akt pathway through its sex hormone-binding globulin-like region. J Neurosci 30: 15521-15534.

Zhu S, Wurdak H, Wang Y, Galkin A, Tao H, Li J, Lyssiotis CA, Yan F, Tu BP, Miraglia L, et al. 2009. A genomic screen identifies TYRO3 as a MITF regulator in melanoma. Proc Natl Acad Sci 106: 17025-17030.

Zhu D, Wang Y, Singh I, Bell RD, Deane R, Zhong Z, Sagare A, Winkler EA, Zlokovic BV. 2010. Protein S controls hypoxic/ischemic blood-brain barrier disruption through the TAM receptor Tyro3 and sphingosine 1phosphate receptor. Blood 115: 4963-4972.

Zong C, Yan R, August A, Darnell JE Jr, Hanafusa H. 1996. Unique signal transduction of Eyk: Constitutive stimulation of the JAK-STAT pathway by an oncogenic receptortype tyrosine kinase. EMBO J 15: 4515-4525. 


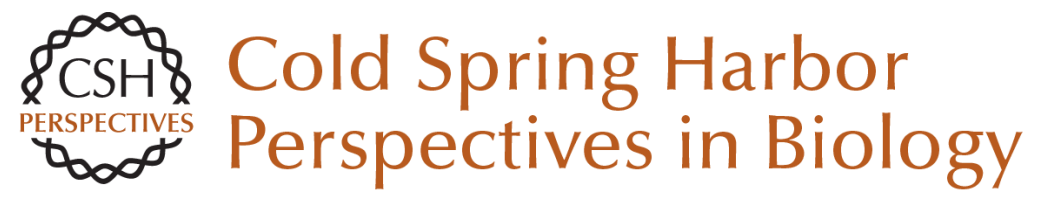

\section{Biology of the TAM Receptors}

Greg Lemke

Cold Spring Harb Perspect Biol 2013; doi: 10.1101/cshperspect.a009076

Subject Collection Signaling by Receptor Tyrosine Kinases

CSF-1 Receptor Signaling in Myeloid Cells

E. Richard Stanley and Violeta Chitu

The EGFR Family: Not So Prototypical Receptor Tyrosine Kinases

Mark A. Lemmon, Joseph Schlessinger and Kathryn M. Ferguson

Tie2 and Eph Receptor Tyrosine Kinase Activation and Signaling

William A. Barton, Annamarie C. Dalton, Tom C.M. Seegar, et al.

The Spatiotemporal Organization of ErbB

Receptors: Insights from Microscopy

Christopher C. Valley, Keith A. Lidke and Diane S. Lidke

Insulin Receptor Signaling in Normal and Insulin-Resistant States

Jérémie Boucher, André Kleinridders and C. Ronald Kahn

Central Role of RET in Thyroid Cancer Massimo Santoro and Francesca Carlomagno

Receptor Tyrosine Kinase-Mediated Angiogenesis Michael Jeltsch, Veli-Matti Leppänen, Pipsa Saharinen, et al.

Biology of the TAM Receptors Greg Lemke
The Genesis of Tyrosine Phosphorylation Tony Hunter

Structure-Function Relationships of ErbB RTKs in the Plasma Membrane of Living Cells

Donna J. Arndt-Jovin, Michelle G. Botelho and Thomas M. Jovin

Receptor Tyrosine Kinases: Legacy of the First

Two Decades Joseph Schlessinger

The Role of Ryk and Ror Receptor Tyrosine Kinases in Wnt Signal Transduction Jennifer Green, Roel Nusse and Renée van Amerongen

Regulation of Receptor Tyrosine Kinase Ligand Processing Colin Adrain and Matthew Freeman

Molecular Mechanisms of SH2- and PTB-Domain-Containing Proteins in Receptor Tyrosine Kinase Signaling Melany J. Wagner, Melissa M. Stacey, Bernard A. Liu, et al.

Eph Receptor Signaling and Ephrins Erika M. Lisabeth, Giulia Falivelli and Elena B. Pasquale

Effects of Membrane Trafficking on Signaling by

Receptor Tyrosine Kinases Marta Miaczynska

For additional articles in this collection, see http://cshperspectives.cshlp.org/cgi/collection/

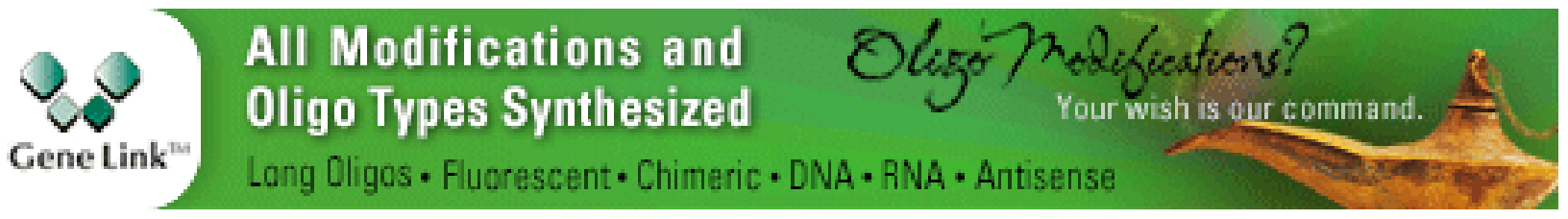


For additional articles in this collection, see http://cshperspectives.cshlp.org/cgi/collection/

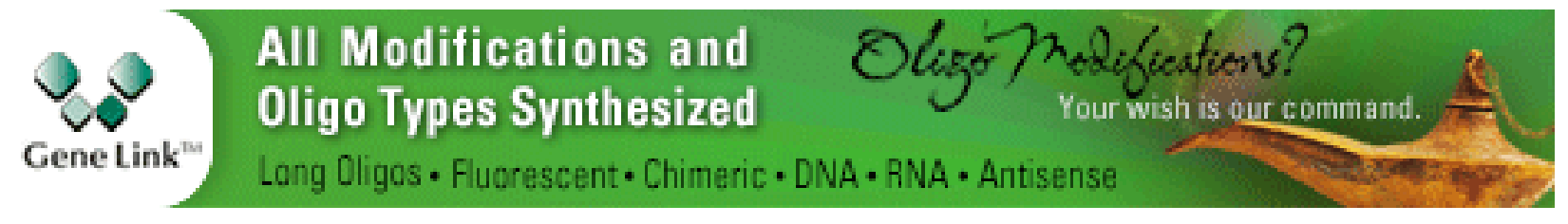

Copyright @ 2013 Cold Spring Harbor Laboratory Press; all rights reserved 